\title{
KAJIAN NILAI ESTETIKA DAN KUALITAS AIR DALAM KONTEKS EKOWISATA PERAIRAN BERKELANJUTAN
}

\author{
Michael Louis Sunaris ${ }^{1}$, Robby Yussac Tallar $^{2}$ \\ ${ }^{1}$ Mahasiswa, Program Studi Teknik Sipil, Fakultas Teknik, Universitas Kristen Maranatha \\ ${ }^{2}$ Dosen, Program Studi Teknik Sipil, Fakultas Teknik, Universitas Kristen Maranatha \\ Email: robbyyussac@yahoo.com
}

\begin{abstract}
ABSTRAK
Indonesia adalah salahsatu dari negara yang sudah mengembangkan ekowisata yang dimilikinya sebagai bagian dari materi pariwisata untuk menarik wisatawan baik lokal maupun manca negara. Salah satu jenis dari ekowisata yang berpotensial tinggi di Indonesia adalah ekowisata perairan. Ekowisata perairan dapat menjadi salah satu faktor kunci dalam mendukung keberlanjutan dan perlindungan lingkungan. Sementara itu, peranan ilmu Teknik Sipil kaitannya dalam ekowisata perairan adalah bagaimana suatu konstruksi dapat mendukung konsep keberlanjutan ekowisata perairan, dan terkhusus untuk bidang keairan sendiri dibutuhkan suatu standar dan ukuran dalam hal nilai estetika dan kualitas air pada badan air yang dijadikan ekowisata perairan. Di Indonesia, indeks yang digunakan untuk mengukur status perairan pada kawasan ekowisata perairan adalah indeks STORET. Indeks STORET merupakan parameter-parameter kualitas air yang ditentukan dari aspek fisika, kimia, dan mikrobiologi. Secara prinsip, metode ini membandingkan antara data kualitas air dengan baku mutu air yang disesuaikan dengan peruntukannya untuk menentukan status badan air yang diperlukan di dalam menerapkan konsep ekowisata keairan yag berkelanjutan. Indeks STORET ini sangat lengkap bila ditinjau dari segi parameter kualitas air yang diukurnya namun bila mempertimbangkan faktor biaya, kekompleksan masalah dan hal lainnya, masih diperlukan metode lain yang lebih sederhana, ekonomis dan mudah untuk diterapkan namun dapat mewakili status perairan tersebut. Terlebih lagi, nilai estetika juga perlu diperhitungkan dalam konteks ekowisata perairan berkelanjutan karena seharusnya nilai estetika dan kualitas air saling terkait satu sama lain. Para pemangku kebijakan (stakeholders) diharapkan dapat menggunakan metode pengukuran status kualitas perairan ini dalam menerapkan konsep ekowisata perairan yang berkelanjutan.

Kata Kunci: status perairan, indeks STORET, ekowisata perairan berkelanjutan.
\end{abstract}

\begin{abstract}
Indonesia is one of the countries that has developed its ecotourism as part of tourism material to attract tourists both local and foreign. One type of high potential ecotourism in Indonesia is aquatic ecotourism. Aquatic ecotourism can be one of the key factors in supporting sustainability and environmental protection. Meanwhile, the role of Civil Engineering in relation to aquatic ecotourism is how a construction can support the concept of sustainability of aquatic ecotourism, and specifically for the field of water itself, a standard and measure of the aesthetic value and water quality of water bodies is used as aquatic ecotourism. In Indonesia, the index used to measure the status of water in the ecotourism area is the STORET index. The STORET index is water quality parameters determined from the physical, chemical and microbiological aspects. In principle, this method compares water quality data with water quality standards adjusted for their purpose to determine the status of water bodies needed in applying the concept of sustainable water ecotourism. This STORET index is very complete when viewed in terms of the water quality parameters it measures but when considering financial or cost factors, complexity of problems and other matters, more simple, economical and easy methods to apply are still needed but can represent the status of the waters. Moreover, the aesthetic value also needs to be taken into account in the context of sustainable aquatic ecotourism because the aesthetic value and water quality should be related to one another. The stakeholders are expected to be able to use this method of measuring the status of water quality in applying the concept of sustainable aquatic ecotourism.
\end{abstract}

Keywords: water status, STORET index, ecotourism. 


\section{PENDAHULUAN}

Peningkatan jumlah penduduk yang pesat diiringi dengan aktivitasnya biasanya mendorong juga tingkat pertumbuhan ekonomi di dalamnya. Namun hal tersebut juga berakibat pada peningkatan perubahan tata guna lahan yang menghasilkan berbagai jenis limbah (effluent) baik dari sektor rumah tangga, pertanian/perkebunan, terlebih lagi sektor industri yang tentunya menyumbang peranan cukup besar kepada keberlanjutan lingkungan sekitarnya. Berbagai jenis limbah tersebut tentunya membawa dampak buruk atau pencemaran bagi lingkungan termasuk pencemaran wilayah keairan atau badan air. Sebagai salah satu dari beberapa negara yang memiliki riwayat sejarah panjang dalam mengatasi pencemaran keairan, Indonesia tentunya terus berupaya mencari solusi yang tepat guna sekaligus metode pengukuran dan analisa yang baik, murah dan dapat diterapkan di berbagai wilayah di Indonesia di dalam mengatasi permasalahan keairan terutama bila dikaitkan dalam konteks ekowisata perairan berkelanjutan.

Sejak beberapa decade yang lalu, berbagai usaha telah dilakukan baik oleh pemerintah Indonesia maupun pihak swasta lainnya untuk mengatasi hal ini namun usaha tersebut masih belum mencapai hasil yang maksimal dan masih bersifat sementara dan sebagian (partial). Oleh karena itu, pentingnya suatu usaha lebih maupun kesadaran dari seluruh pemangku kebijakan (stakeholders) untuk terus mengatasi permasalahan perairan terutama peningkatan kualitas air pada badan air tersebut yang dapat meningkatkan nilai estetika yang dimilikinya. Hal ini penting untuk diperhatikan dan diupayakan di waktu sekarang ini dikarenakan pengembangan industri ekowisata perairan yang semakin ditingkatkan di Indonesia untuk menarik banyak wisatawan yang ujungnya dapat meningkatkan perekonomian daerah maupun negara.

Dampak negatif seringkali timbul pada kegiatan pariwisata perairan konvensional. Dampak negatif ini bukan hanya berupa kerusakan lingkungan seperti permasalahan sampah yang berada disekitar lingkungan saja, akan tetapi juga secara spesifik dapat menurunkan kualitas air pada badan air tersebut sehingga dapat mempengaruhi nilai estetika dari badan air tersebut secara keseluruhan. Terkait dengan industri pariwisata perairan, dampak negatif ini harus dapat diukur dan dianalisa dengan melihat variabel indikator yang menunjukkan suatu nilai tertentu dan dibandingkan dengan standar yang telah ada. Oleh karena itu diperlukan suatu indeks yang terkait dalam menilai kualitas suatu kondisi perairan dalam kerangka metodologi yang sesuai dengan kondisi masingmasing area yang ditinjau maupun peruntukan badan airnya.

Terkait dengan hal tersebut, maka tulisan ini dibuat dengan tujuan disamping untuk mengkaji permasalahan perairan yang terkait dengan pengembangan industri ekowisata 
perairan kedepannya dalam menjaga keberlangsungan lingkungannya. Tulisan ini juga bertujuan untuk menawarkan suatu indeks perairan dan metodologi yang dapat digunakan untuk menilai kondisi perairan eksisting dengan mengelaborasi variabel indikator yang terkait terutama indikator ekologi yang (mungkin) selama ini masih belum dianggap penting dalam mengambil suatu keputusan terkait dengan pengembangan industri ekowisata perairan.

Sebelum masuk lebih jauh ke dalam pembahasan yang lebih dalam lagi, perlu diketahui terlebih dahulu pengertian dasar dari ekowisata atau ekoturisme. Secara sederhananya ekowisata adalah salah satu aktivitas pariwisata yang berwawasan lingkungan dengan mengutamakan aspek konservasi alam, aspek pemberdayaan sosial budaya ekonomi masyarakat lokal serta aspek pembelajaran dan pendidikan. Jadi ekowisata perairan berarti aktivitas pariwisata perairan yang berwawasan lingkungan dengan menjaga keberlanjutannya dari berbagai aspek terutama aspek perairannya yang badan air yang berada di darat maupun lautan. Pada awalnya pariwisata perairan konvensional mengabaikan dampak lingkungan yang terjadi karena salah satunya tidak melibatkan aspek ekologis di dalamnya.

Banyak pencemaran di wilayah perairan yang terjadi sehingga mempengaruhi kualitas perairan itu sendiri. Harapannya, dengan penerapan konsep ekowisata perairan, maka pengembangan industri pariwisata perairan dapat dijalankan dengan cara yang lebih ramah lingkungan dalam membawa wisatawan ke objek wisata alam perairan yang eksotis. Proses kunjungan yang sebelumnya memanjakan wisatawan namun memberikan dampak negatif kepada lingkungan harus dapat mulai dikurangi dan diganti dengan konsep ekowisata yang lebih ramah lingkungan. Oleh karena itu, konsep ekowisata perairan harus memasukan aspek ekologi dalam penerapannya (Gambar 1).

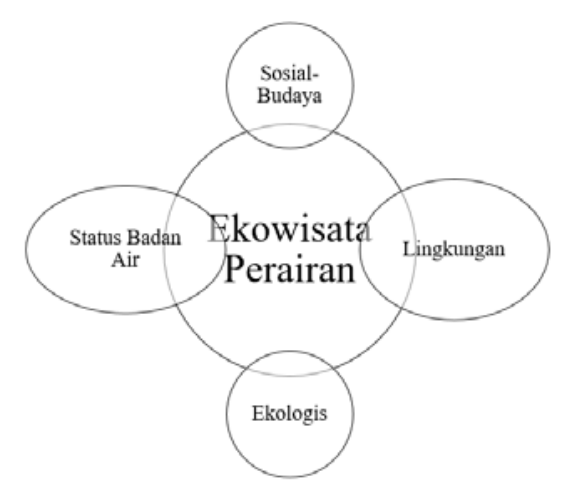

Gambar 1. Hubungan Aspek yang Terkait dengan Ekowisata Perairan 


\section{KONSEP DASAR EKOWISATA PERAIRAN}

Dalam penelitian ini diperlukan kajian atau landasan teori yang mendukung seperti definisi ekowisata perairan dan pencemaran air secara umum. Ekowisata perairan adalah kegiatan pariwisata berbasis kelestarian lingkungan yang mengandalkan daya tarik perairan dan seluruh elemen yang berada di dalamnya. Ekowisata perairan di Indonesia terbilang masih sangat luas untuk digarap dan dijadikan potensi pariwisata unggulan karena secara alamiah memiliki nilai estetika yang tinggi.

Konsep ekowisata perairan sendiri mengedepankan potensi sumberdaya lokal dan meminimalisir terjadinya perubahan tata guna lahan, maupun tatanan sosial dan budaya masyarakat yang telah ada sebelumnya. Masyarakat diharapkan dapat berperan sebagai pelaku dan penerima manfaat utama, disamping itu ekowisata juga mendukung upaya pengembangan ekonomi yang berkelanjutan karena memberikan kesempatan kerja dan menjadi salah satu sumber penghasilan masyarakat untuk meningkatkan kesejahteraannya. Ekowisata dapat berupa kunjungan wisata ke daerah yang memiliki lingkungan alamnya masih asli, dengan menghargai warisan budaya dan alamnya, mendukung upaya-upaya konservasi, tidak menghasilkan dampak negatif, dan memberikan keuntungan sosial ekonomi serta menghargai partisipasi penduduk lokal.

Terkait dengan kualitas air, menurut Keputusan Menteri Negara Lingkungan Hidup No.115 Tahun 2003 tentang Pedoman Penentuan Status Mutu Air, definisi mutu air adalah kondisi kualitas air yang diukur dan atau diuji berdasarkan parameter-parameter tertentu dan metode tertentu berdasarkan peraturan perundang-undangan yang berlaku. Status kualitas air adalah tingkat kondisi kualitas air yang menunjukkan kondisi tercemar atau kondisi baik pada suatu badan air dalam waktu tertentu dengan membandingkan dengan baku mutu air yang telah ditetapkan pemerintah sebelumnya sesuai dengan peruntukan atau fungsi air di badan air tersebut. Oleh karena itu, diperlukan suatu cara atau metode untuk menentukan status perairan tersebut.

Indeks STORET merupakan salah satu metode untuk penentuan status mutu air atau kualitas badan air yang umum digunakan di Indonesia. Indeks STORET menggunakan parameter-parameter yang telah ditetapkan untuk dilakukan pengecekan apakah parameter-parameter tersebut memenuhi atau melampaui baku kualitas air pada suatu badan air. Prinsip kerja dari indeks STORET adalah melakukan perbandingan antara data kualitas air dengan baku kualitas air yang disesuaikan dengan peruntukannya guna menentukan status mutu atau kualitas air. Apabila hasil pengukuran tersebut memenuhi baku mutu airnya yaitu bila hasil pengukuran kurang dari baku mutu, maka diberi nilai nol. Namun sebaliknya apabila hasil pengukuran tersebut tidak memenuhi 
baku mutu air yaitu bila hasil pengukuran lebih besar dari baku mutu air, maka diberi skor atau nilai seperti pada Tabel 1.

Tabel 1. Sistem Penilaian yang Digunakan pada Indeks STORET

\begin{tabular}{|c|c|c|c|c|}
\hline \multirow{3}{*}{$\begin{array}{c}\text { Jumlah } \\
\text { Sampel }\end{array}$} & \multirow{2}{*}{ Nilai } & \multicolumn{3}{|c|}{ Parameter } \\
\cline { 3 - 5 } & & Fisika & Kimia & Mikrobiologi \\
\hline$<10$ & Maksimum & -1 & -2 & -3 \\
\cline { 2 - 5 } & Minimum & -1 & -2 & -3 \\
\cline { 2 - 5 } & Rata-Rata & -3 & -6 & -9 \\
\hline \multirow{2}{*}{$\geq 10$} & Maksimum & -2 & -4 & -6 \\
\cline { 2 - 5 } & Minimum & -2 & -4 & -6 \\
\cline { 2 - 5 } & Rata-Rata & -6 & -12 & -18 \\
\hline
\end{tabular}

Adapun sistematika kerja dari indeks STORET adalah sebagai berikut:

1. Pengumpulan data kualitas air dari tiap-tiap parameter dan debit air dilakukan secara periodik (time series).

2. Membandingkan data hasil pengukuran kualitas air dengan nilai baku mutu sesuai dengan peruntukan atau kelas air.

3. Jika hasil pengukuran dari parameter-parameter kualitas air tersebut telah memenuhi nilai baku mutu air maka diberi skor 0 .

4. Jika hasil pengukuran dari parameter-parameter kualitas air tersebut tidak memenuhi nilai baku mutu air, maka diberi skor atau nilai seperti yang tertera pada Tabel 1.

5. Jumlah nilai negatif dari seluruh parameter dihitung dan ditentukan status mutunya dari jumlah skor yang didapat dengan menggunakan sistem nilai.

6. Jika dalam perhitungan, tidak ditemukan nilai ambang batas suatu parameter yang diukur, maka parameter tersebut tidak perlu dihitung.

Berdasarkan hasil tersebut barulah ditentukan status kualitas air pada suatu badan air tertentu.

\section{NILAI ESTETIKA DALAM STANDAR KUALITAS AIR}

Dalam beberapa tahun terakhir, kegiatan antropogenik mengakibatkan menurunnya kualitas air atau degradasi di lingkungan badan air atau perairan, dan hal ini juga tentunya berpengaruh kepada nilai estetika di dalamnya. Nilai estetika tidaklah mudah untuk dinilai karena beberapa kendala antara lain faktor subyektivitas dari masyarakat dan juga 
karakteristik khusus dari suatu area tertentu. Oleh karena itulah diperlukan suatu standar dan pengukuran yang dapat diterima oleh masyarakat untuk menilai bagaimana lingkungan badan air tertentu dapat mendukung konsep ekowisata berkelanjutan kedepannya.

Beberapa penelitian sebelumnya yang terkait dengan nilai estetika badan air telah dilakukan dan didiseminasi. Menurut Tallar (2017), istilah nilai estetika dalam kaitannya dengan badan air didefinisikan secara berbeda-beda, dan tergantung pada tujuan atau peruntukan dari badan air tersebut. Beberapa peneliti sebelumnya juga ada yang telah mendasarkan nilai estetika air pada kejernihan dan warnanya, sementara yang lain berfokus pada aspek sosio-ekonomi lingkungan air. Bernal et al. (1999) telah mengembangkan Aesthetic Quality Index (AQI), yang mempertimbangkan tiga parameter berikut: rasa dan bau, kekeruhan, dan warna.

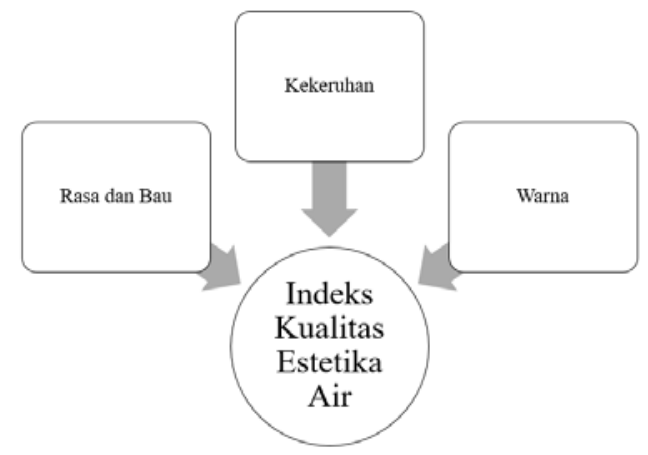

Gambar 2. Parameter Pembentuk Indeks Kualitas Estetika Air (Bernal et al, 1999)

Sementara itu, nilai estetika pada suatu wilayah perairan adalah suatu keindahan yang dapat dirasakan oleh manusia saat berada di wilayah badan air atau perairan tersebut. Nilai estetika perairan ini diberikan oleh status kualitas air maupun atribut atau elemen pendukung lingkungan sekitarnya. Atribut atau elemen tersebut seringkali dipengaruhi dari effluent dalam hal ini bisa berupa limbah yang masuk ke dalam perairan akan mempengaruhi kualitas air seperti misalnya kandungan bahan organik. Kandungan bahan organik yang tinggi dapat memberikan dampak positif bagi perairan sehingga menjadi kaya akan nutrien atau yang dikenal dengan sebutan eutrofikasi namun juga dapat memberikan dampak negatif yaitu menurunnya produktivitas perairan dan nilai estetika. Disamping itu, perlu dipikirkan juga atribut lainnya seperti lansekap wilayah perairan tersebut. Hal ini tentunya menjadi penting sebagai salah satu aspek penentu dalam konsep ekowisata berkelanjutan. Lansekap yang baik dapat mendukung 
kenyamanan maupun estetika pengunjung atau wisatawan yang dating ke lokasi perairan tersebut.

Oleh karena itu dibutuhkan pengembangan model, penambahan parameterparameter dan perumusan kembali di dalam merencanakan pengukuran indeks kualitas air. Di Indonesia, indeks yang digunakan untuk mengukur status perairan pada kawasan ekowisata perairan adalah indeks STORET. Indeks STORET merupakan parameterparameter kualitas air yang ditentukan dari aspek fisika, kimia, dan mikrobiologi yang dapat menentukan status badan air yang diperlukan di dalam menerapkan konsep ekowisata keairan yag berkelanjutan, namun belum mewakili nilai estetika secara keseluruhan dari wilayah perairan ekowisata tersebut mengingat parameter yang dipertimbangkan dalam indeks STORET hanya memperhitungkan unsur kualitas air pada badan air saja. Layout, desain dan variasi dari elemen-elemen biotik maupun abiotik yang ada di wilayah perairan tersebut turut juga berkontribusi di dalam menentukan nilai estetika wilayah perairan dalam konsep ekowisata berkelanjutan.

\section{KESIMPULAN DAN REKOMENDASI}

Secara prinsip, kajian ini memberikan informasi bahwa adalah sesuatu yang penting untuk dipertimbangkan ke depannya terkait dengan nilai estetika dan kualitas air pada suatu wilayah perairan atau badan air tertentu. Indeks STORET telah digunakan dan indeks ini membandingkan antara data kualitas air dengan baku mutu air yang disesuaikan dengan peruntukannya untuk menentukan status badan air yang diperlukan di dalam menerapkan konsep ekowisata keairan yag berkelanjutan.

Indeks STORET ini sangat lengkap bila ditinjau dari segi parameter kualitas air yang diukurnya namun bila mempertimbangkan faktor biaya, kekompleksan masalah dan hal lainnya, masih diperlukan metode lain yang lebih sederhana, ekonomis dan mudah untuk diterapkan namun dapat mewakili status perairan tersebut. Terlebih lagi, nilai estetika juga perlu diperhitungkan dalam konteks ekowisata perairan berkelanjutan karena seharusnya nilai estetika dan kualitas air saling terkait satu sama lain dengan mempertimbangkan bobot dari parameterparameter yang akan ditentukan.

Para pemangku kebijakan (stakeholders) diharapkan dapat menggunakan metode pengukuran status kualitas perairan ini dalam menerapkan konsep ekowisata perairan yang berkelanjutan seperti sungai, danau, pantai maupun 
wilayah perairan lainnya dengan berbagai kegiatan wisata perairan yang dapat dilakukan di dalamnya.

\section{DAFTAR PUSTAKA}

1. Cottet, M., Piégay, H., Bornette, G. (2013). Does human perception of wetland aesthetics and healthiness relate to ecological functioning? J. Environ. Manag., 128, 1012-1022.

2. Corrigan, J.R., Egan, K.J., Downing, J.A., Likens, G. (2009). Aesthetic Values of Lakes and Rivers; Iowa City: Elsevier, Inc.

3. Jennings, G. (2007). Chapter 1: Water-based tourism, sport, leisure, and recreation experiences. In Water-Based Tourism, Sport, Leisure, and Recreation Experiences; Gayle, J., Ed.; Boston: Butterworth-Heinemann.

4. Tallar, R.Y., Suen, J. P. (2016). Aquaculture water quality index: A low-cost index to accelerate aquaculture development in Indonesia. Aquac. Int., 24, 295312. 